\title{
THE APPLICATION OF THE DOCTRINE OF RES JUDICATA IN THE CONTEXT OF THE AFRICAN COURT ON HUMAN AND PEOPLES' RIGHTS: ANALYSIS OF THE COURT'S DECISIONS IN THE GOMBERT AND DEXTER CASES
}

\begin{abstract}
As part of an ongoing discussion on the proliferation of the human rights judicial mechanism, this article critically analyses and unpacks the only two examples where the African Court had to decide on the application of the doctrine of res judicata under Article 56(7) of the African Charter. The Court declared both applications inadmissible on the grounds of their previous settlements by the ECOWAS Court of Justice and the United Nations Human Rights Committee. The article demonstrates that while the Court's decision in the Gombert case appears to be correct in principle, its finding in the Dexter case is highly questionable and unconvincing.
\end{abstract}

* PhD candidate, Faculty of Law, Palacký University Olomouc, ORCID ID: 00000002-3756-3718; e-mail: hazhar.jamali@gmail.com.

** Senior Lecturer in International Law, Head of the Centre for International Humanitarian and Operational Law, Faculty of Law, Palacký University Olomouc, ORCID ID: 0000-0003-2333-9341; e-mail: martin.faix@upol.cz.

*** The authors received financial support from the Palacký University Olomouc for the research, authorship, and/or publication of this article within the Project No. IGA-PF-2020-012; SPP 437100060/31. 


\section{Keywords}

Res judicata - forum shopping - admissibility - jurisdictional overlap - African Court on Human and Peoples' Rights - Article 56(7) of the African Charter

\section{INTRODUCTION}

In recent decades, there has been a sharp increase in the number of international tribunals and bodies and a greater willingness on the part of states to accept the jurisdiction of international adjudicative mechanisms. ${ }^{1}$ Among the consequences of this rapid proliferation is the risk of the overlapping jurisdictions of different judicial bodies. This judicial overlap is prominent in the international human rights arena. ${ }^{2}$

One result of the proliferation of international adjudicatory mechanisms with competing personal and material jurisdictions is so-called forum shopping - the possibility for the applicant to submit a petition to the most favourable forum in the region. ${ }^{3}$ Forum shopping is generally understood to be a negative phenomenon, as it has the potential to undermine the authority of the judiciary, make conflicting decisions, or allow endless litigation. ${ }^{4}$ One of the principles restricting forum shopping is the doctrine of res judicata, also known as the 'doctrine of finality',

${ }^{1}$ L. Chazournes, "Plurality in the Fabric of International Courts and Tribunals: The Threads of a Managerial Approach", European Journal of International Law, 2017, Volume 28, p. 13-14; L.G.P. Specker, "Remedying the Normative Impacts of Forum Shopping in International Human Rights Tribunals", the New Zealand Postgraduate Law e-Journal, 2005, Issue 2, p. 2; See generally, E. A. Posner, J. C. Yoo, “Judicial Independence in International Tribunals", California Law Review, 2005, Volume 93.

2 Specker, supra note 1; J. Pauwelyn, L. E. Salles, "Forum Shopping before International Tribunals: (Real) Concerns, (Im)Possible Solutions", Cornell International Law Journal, 2009, Volume 42, p. 80; See generally, P. Sands, C. P. R. Romano, R. Mackenzie, Y. Shany, Manual on International Courts and Tribunals, Oxford University Press, $2^{\text {nd }}$ ed., 2010.

3 J. Pauwelyn, L. E. Salles, supra note 2; A. Appazov, "In the Jungle of the Unregulated: Towards Extra-Legal Regulatory Approaches in Addressing Cybercrime", International and Comparative Law Review, 2017, Volume 17, p. 90.

${ }^{4}$ M. Petsche, "What's Wrong with Forum Shopping? An Attempt to Identify and Assess the Real Issues of a Controversial Practice", the International Lawyer, 2011, Volume 45, No. 4, p. 1009-1019; See generally, C. A. Whytock, “The Evolving Forum Shop- 
which stipulates that "the final judgment of a competent judicial forum is binding upon the parties" and thus cannot be re-litigated. ${ }^{5}$

This article examines the doctrine of res judicata in the context of the African Court on Human and Peoples' Rights (African Court or Court). It takes the view that Article 56(7) of the African Charter on Human and People's Rights (African Charter or Charter) reiterates the rule of res judicata. The article examines the Court's only two decisions in the Dexter and Gombert applications and demonstrates that, while the Court's decision in the Gombert case may be correct in principle, its finding in the Dexter case is, arguably, questionable and unconvincing.

While the challenges and issues resulting from the jurisdictional overlap of international human rights bodies are a common theme running through the literature and discussed by stakeholders and academics, ${ }^{6}$ very limited scholarly attention has been paid to this topic in the context of the African Court, the only Pan-African judicial human rights body in the continent. This article therefore aims to contribute to

ping System", Cornell Law Review, 2011, Volume 96; See, generally, L. R. Helfer, "Forum Shopping for Human Rights", University of Pennsylvania Law Review, 1999, Volume 148, Issue 2.

5 Y. Shany, The Competing Jurisdictions of International Courts and Tribunals, Oxford University Press, 2003, p. 22-23.

6 A. F. Lowenfeld, "Forum Shopping, Antisuit Injunctions, Negative Declarations, and Related Tools of International Litigation", American Journal of International Law, 1997, Vol. 91, p. 314-324; A. G. Koroma, "Asserting Jurisdiction by the International Court of Justice", in P. Capps, M. Evans, S. Konstadinidis (eds.), Asserting jurisdiction.: International and European legal perspectives, 2003, Hart Publishing; G. Walters, L. Gretta, "Fitting a Square Peg into a Round Hole: Do Res Judicata Challenges in International Arbitration Constitute Jurisdictional or Admissibility Problems?", Journal of International Arbitration, 2012, Volume 29, Issue 6, p. 651-680; V. Lowe, “Vaughan, Overlapping Jurisdiction in International Tribunals", Australian Year Book of International Law, 1999, Volume 20, p. 191-201; P. Webb, "Scenarios of Jurisdictional Overlap Among International Courts", Revue québécoise de droit international, 2006, Volume 19; A. Huneeus, "Legitimacy and Jurisdictional Overlap: The ICC and the Inter-American Court in Colombia", in N. Grossman, H. Cohen, A. Follesdal, G. Ulfstein (eds.), Legitimacy and International Courts (Studies on International Courts and Tribunals), Cambridge University Press, 2018; K. Oellers, "Multiplication of International Courts and Tribunals and Conflicting Jurisdiction: Problems and Possible Solutions", Max Planck Yearbook of United Nations Law, 2001, Volume 5, p. 67-104; L. Barrionuevo, "The Multiplication of International Jurisdictions And The Integrity Of International Law", ILSA Journal of International \& Comparative Law, 2008, Vol. 15, Issue 1; Shany, supra note 5. 
closing this gap by examining the application of the said doctrine in respect of the African Court.

The article proceeds as follows: section I briefly examines the concept of admissibility and its regulation in international law; section II analyses the application of the res judicata doctrine in the context of African Court. It presents a summary of the Court's decisions in the Gombert and Dexter applications, focusing on the Court's findings in relation to Article 56(7) of the Charter. Part III of the article evaluates the Court's decision in the Gombert and Dexter cases and attempts to expose the Court's interpretation and application of the res judicata principle. The last section of the article summarises the key findings of this paper.

\section{The Concept of Admissibility and its Regulations IN INTERNATIONAL LAW}

In international law, the concept of admissibility concerns the power of a tribunal to exercise its jurisdiction in a particular claim. ${ }^{7}$ It is the rule of admissibility that defines when a court or tribunal should dismiss a case or continue to decide on the merit. The admissibility requirement is therefore understood to serve as a screening mechanism between national and international courts or among international institutions. ${ }^{8}$ The logic is that the international mechanisms should act only as the instance of last resort thereby leaving the primary responsibility to the national institutions in the adjudication of disputes. In the absence of such a screening mechanism, international institutions will be there-

7 Y. Shany, "The concept of jurisdiction and admissibility in international adjudication', in H Lauterpacht (ed.), Questions of Jurisdiction and Admissibility before International Courts, Cambridge University Press, 2015, p. 779-780; M. J. Nkhata, "Res judicata and the Admissibility of Applications before the African Court on Human and Peoples' Rights: a Fresh Look at Dexter Eddie Johnson v. Republic of Ghana", The Law \& Practice of International Courts and Tribunals, 2020, Volume 19: Issue 3, p. 476.

${ }^{8}$ F. Viljoen, "Communications under the African Charter: Procedure and Admissibility", in M. Evans, R. Murray (eds.), The African Charter on Human and Peoples' Rights: The System in Practice, 1986-2006, Cambridge University Press, 2008, p. 76-138. 
fore overburdened with a high number of cases that will reduce their efficiency. ${ }^{9}$

Among the principles related to the concept of admissibility is the rule of res judicata, which bars any court from exercising jurisdiction over a dispute that has already been settled by another tribunal. ${ }^{10}$ In other words, a judgement, delivered by a judicial body, carries a preclusive effect on the successive proceedings over the same matter. It is claimed that the doctrine of res judicata is a general principle of international law within the meaning of Article 38(1) of the Statute of the International Court of Justice. ${ }^{11}$ In addition, it is argued that the res judicata doctrine satisfies the requirements of state practice and opinio juris for being considered as a rule of customary international law..$^{12}$ Among human rights bodies which do not admit cases that have already been decided by other institutions is the African Court, as will be elaborated on in the next section.

In support of the rule of res judicata, the interests of what is private and what is public are often mentioned by scholars. ${ }^{13}$ Private justice demands that a defendant should not be sued multiple times in respect of the same transgression. As a matter of public policy, it ensures the economic efficiency of the judicial process, brings an end to litigation, and furthers legal certainty by avoiding a situation where there may

9 Ibid., p. 88.

${ }^{10}$ Shany, supra note 5, p. 23.

11 Waste Management, Inc. v. United Mexican States ("Number 2"), Decision on Mexico's Preliminary Objection Concerning the Previous Proceedings of 26 June 2002, ICSID Case No. ARB(AF)/00/3, 6 ICSID Reports 549, para. 39.

12 This can be illustrated by the general tendency of states which often question the admissibility of a case that was previously settled by another forum; Nkhata, supra note 7, p. 480-481.

${ }^{13}$ N. Ridi, "Precarious Finality? Reflections on Res Judicata and the Question of the Delimitation of the Continental Shelf Case", Leiden Journal of International Law, 2018, Volume 31 , Issue 2, p. 2; M. Kreca, “The res judicata rule in jurisdictional decisions of the international Court of justice", Belgrade Law Review, 2014, Volume 62, Issue 3, 2014, p. 18-19; Shany, supra note 5, p. 170-171; Nkhata, supra note 7, P. 480; W. S. Dodge, "Res Judicata", in Oxford Public International Law, Max Planck Encyclopaedia of Public International Law, 2006, available at SSRN: https://ssrn.com/abstract=2778726 (last accessed 20.07.2021). 
be contradictory decisions being taken on the same matter by different courts. ${ }^{14}$

There are a number of conditions which need to be fulfilled in order to apply the rule of res judicata in a proceeding. ${ }^{15}$ Firstly, the competing procedures should involve the same issue and the same party, of which the latter one has been narrowly construed by international tribunals. ${ }^{16}$ Beside this, the rule of res judicata requires that there must be a binding judgment rendered by a competent judicial body. ${ }^{17}$ This illustrates that the findings of non-judicial bodies do not have automatic res judicata effect. It should be also noted that if a judgment is not rendered on merit, its res judicata effect does not apply in the successive proceedings. ${ }^{18}$ When these conditions are met, a court should declare the case inadmissible. ${ }^{19}$

\section{THE DOCTRINE OF RES JUDICATA IN THE CONTEXT OF THE AfRican COURT}

Within the African regional human rights system, the principle of res judicata is regulated by the provision of Article 56 (7) of the African Charter which stipulates that "cases which have been settled by those States involved in accordance with the principles of the Charter of the United Nations, or the Charter of the Organisation of African Unity or the provisions of the present Charter" ${ }^{\prime 20}$ shall not be admitted. The African Court, for the only second time in its history, was faced with a situation where it had to examine the res judicata effect of decisions rendered by

14 Shany, supra note 5, p. 156.

15 A. Reinisch, "The Use and Limits of Res Judicata and Lis Pendens as Procedural Tools to Avoid Conflicting Dispute Settlement Outcomes", The Law and Practice of International Courts and Tribunals, 2004, Volume 3, p. 76-80; Nkhata, supra note 7, p. 482.

16 Shany, supra note 5, p. 24-25.

17 Ibid.

18 Ibid., p. 24-28.

19 Application of the Convention on the Prevention and Punishment of the Crime of Genocide (Bosnia and Herzegovina v. Serbia and Montenegro), Judgment, I.C.J. Reports 2007, para. 139; Nkhata, supra note 7, p. 482.

20 African Charter on Human and Peoples' Rights (adopted 27 June 1981, entered into force 21 October 1986) (1982) 21 ILM 58, art. 56 (7). 
judicial and quasi-judicial bodies. Given the fact that res judicata is a central theme of this paper, it is necessary to scrutinise the Court's position on the admissibility of both cases in detail.

\section{Jean-Claude Gombert v. Côte D'ivoire}

The first time the African Court dealt with the question of res judicata was in the case of Jean-Claude Gombert $v$. Côte d'Ivoire. ${ }^{21}$ The origin of the case related to a contractual dispute between private parties which was brought before various domestic courts in the Côte $d^{\prime} I v o i r e .{ }^{22}$ In the domestic proceedings, while some of the decisions were in favour of the applicant, others were not. ${ }^{23}$ Believing that some of those judgments were in violation of his rights, the applicant submitted a case to the court of the Economic Community of West African States (ECOWAS court). The ECOWAS court rendered two merit judgments on the case, which in both declared that the application was baseless. ${ }^{24}$

Having failed to get a remedy at the sub-regional level, the applicant referred the case to the African Court alleging the violation of his right to equality before the law, to fair trial and effective remedy under the Charter and under other international human rights documents. ${ }^{25}$ The respondent state challenged the admissibility of the case on several grounds including that of its previous settlement by the ECOWAS court, non-exhaustion of local remedies, and belated referral of the case to the African Court. ${ }^{26}$

Following the dismissal of most of the grounds on which challenges to admissibility may be brought, the African Court turned to focus on the provisions of Article 56(7) of the African Charter to examine the admissibility of the application. Focusing on the notion of 'settlement', the Court held that 'settlement', within the meaning of Article 56(7) of the

${ }^{21}$ Jean-Claude Roger Gombert v. Republic of Côte d'Ivoire, ACHPR, Application No, 038/2016, Judgment of 22 March 2018, (Hereinafter referred to as the Gombert case).

${ }^{22}$ Ibid., para 3.

${ }^{23}$ Ibid., para 6.

${ }^{24}$ Ibid., para 7.

${ }^{25}$ Ibid., para 8.

${ }^{26}$ Ibid., paras 23-39. 
Charter, implies the convergence of three major conditions: (i) the identity of the parties, (ii) the identity of the applications or their supplementary or alternative nature or whether the case flows from a request made in the initial case, and (iii) the existence of a first decision on the merits. ${ }^{27}$

Walking through this framework, the African Court noted that the applicant in the case under its review was Mr. Gombert, while the applicant before the ECOWAS court was the AGRILAND Company. However, upon further investigation the Court found that the AGRILAND company had acted as the applicant in the proceedings before the ECOWAS court on behalf of its chairman, Mr. Gombert. ${ }^{28}$ In this respect, the Court held that, despite the fact that the applicant before the ECOWAS court was the AGRILAND company, the rights claimed by that company directly affected the individual rights of Mr. Gombert considering that he was the President, Chief Executive Officer, founder, and majority shareholder of the AGRILAND company. In the light of this, the Court found that the applicants before the ECOWAS court and present communication were identical and that, as such, the first condition had been met. ${ }^{29}$

Furthermore, the Court went on to analyse the second condition, noting that the applicant before the ECOWAS court claimed the violation of those rights which were identical to those alleged in the current communication. ${ }^{30}$ The Court, therefore, held that the second condition was also met as the current case dealt with the same issue as that which the applicant had brought before the ECOWAS court. The Court finally held that given the fact that the ECOWAS court had rendered two judgments on the merit of the same case in accordance with the principle of the African Charter, the matter was deemed to have been settled within the meaning of Article 56(7) of the Charter, and thus the third condition has been also met. ${ }^{31}$ From the foregoing, the Court found that the application had not fulfilled the condition set by Article 56 (7) of the Charter.

\footnotetext{
27 Ibid., para 45.

28 Ibid., para 46.

29 Ibid., para 49.

30 Ibid., paras 50-53.

31 Ibid., para 54.
} 
The case was therefore declared inadmissible on the grounds of its earlier settlement by the ECOWAS court. ${ }^{32}$

\section{Dexter Eddie Johnson v. Republic of Ghana}

The second case in which the African Court dealt with the question of res judicata is the case of Dexter Eddie Johnson v. Republic of Ghana. ${ }^{33}$ While the Court followed its previous approach when determining the admissibility of the Gombert case, it is worth analysing this case as well, since it involves new matters relevant to the development of the Court's jurisprudence on the admissibility question.

In the Dexter case, the applicant claimed that the mandatory imposition of a death sentence for a murder conviction by Ghana had violated his right under Articles 4, 5, and 7 of the African Charter; Articles 6(1), 7 and 14(1) of the International Covenant on Civil and Political Rights (ICCPR); and Article 5 of the Universal Declaration of Human Rights (UDHR). ${ }^{34}$ By its decision of 28 March 2019, the African Court held that while the application passed the admissibility test under Article 56(1) to 56(6) of the Charter, it did not satisfy the admissibility requirement set out by Article 56(7) of the Charter since the matter was previously settled by the United Nations Human Rights Committee (HRC). ${ }^{35}$

To reach this conclusion, the African Court argued that it was not in dispute that Mr. Johnson was the same applicant in the current case and the application brought against Ghana before the HRC. ${ }^{36}$ It further held that although the applicant before the HRC only claimed violation of his right under the ICCPR, the principles invoked were identical to the provisions of the African Charter, which Mr. Johnson had claimed that Ghana violated in the current communication. The Court, therefore, held that the current case dealt with the same issue that the appli-

${ }^{32}$ Ibid., para 61-62.

${ }^{33}$ Dexter Eddie Johnson v. Ghana, Application 016/2017, ACHPR, Application No. 016/2017, Ruling of 28 March 2019 (Jurisdiction and Admissibility), para 57 (Hereinafter referred to as the Dexter case).

34 Ibid., para 13.

${ }^{35}$ Ibid., para $45,56-57$.

36 Ibid., para 49. 
cant had brought before the HRC, which was the mandatory imposition of a death sentence for a murder conviction. ${ }^{37}$

Most importantly, the African Court found that the non-compliance of Ghana with the decision of the HRC is irrelevant when determining the admissibility of the case under Article 56(7) of the Charter. ${ }^{38}$ It noted that it is important only that there has to be a judgment rendered by a body that has a legal mandate to adjudicate disputes at an international level. ${ }^{39}$ It further emphasised that the non-binding nature and non-implementation of the HRC's view were irrelevant in the determination of admissibility, emphasising that it had not admitted applications pending before or settled by the African Commission, despite the non-binding nature of its decisions. ${ }^{40}$ It further pointed out to the principle of ne bis in idem, which prevents states from being held accountable more than once in respect of the same alleged violation of rights. Based on these reasonings, the African Court declared the case inadmissible. ${ }^{41}$

The first controversial point of this case is the Court's lack of assessment in determining the admissibility of the case under Article 56(6) of the Charter. It is not clear how the Court reached a conclusion that the application met the admissibility requirement under the said Article considering that it was filed six years and two months after the exhaustion of local remedies. According to its settled case-law, the African Court assessed the requirement to file an application within a reasonable timeframe on a case by case basis, having considered the particular circumstances of each one..$^{42}$ While the Court has traditionally been very flexible in computing the reasonableness of time, it had dismissed

37 Ibid., para 50.

38 Ibid., para 51.

39 Ibid., para 51.

${ }^{40}$ Ibid., para 54.

${ }^{41}$ Ibid., para 57.

42 Jibu Amir alias Mussa, Saidi Ally alias Mangay v. United Republic of Tanzania, ACHPR, Application 014/2015, judgment of 28 November 2019; Christopher Jonas v. United Republic of Tanzania, ACHPR, Application 011/2015, judgment of 28 September 2017; Mohamed Abubakari v. United Republic of Tanzania, ACHPR, Application 007/2013, judgment of 03 Jun 2016; Alex Thomas v. United Republic of Tanzania, ACHPR, Application 005/2013, judgment of 20 November 2015; Hamad Mohamed Lyambaka v. United Republic of Tanzania, ACHPR, Application 010/2016, judgment of 25 September 2020. 
a number of cases for not meeting this requirement. ${ }^{43}$ This lack of assessment was criticised by Justice Ben Achour. In a dissenting opinion, he objected to the decision of the majority with regard to the fulfilment of admissibility requirement under Article 56(6) of the Charter. Justice Achour pointed out the necessity of filing an application within a reasonable time for ensuring legal safeguards. ${ }^{44}$ In this context, he referred to the practices of the Inter-American Court of Human Rights and the European Court of Human Rights (ECtHR), both of which require applicants to file a case within six months from the exhaustion of local remedies. ${ }^{45}$ He criticized the Court's ignorance of the applicant's failure to justify why he referred the case six years and two months after the exhaustion of local remedies. He noted that such negligence denies Article 56(6) having meaningful effect, and thus it leaves the litigation open-ended. ${ }^{46}$

The second controversial point of this case relates to the Court's position having concluded that the non-binding nature of the HRC's view is irrelevant in the determination of the admissibility of the case. This finding was also criticised by Justice Ben Achour who argued that, assuming that the said timeframe is reasonable, the case should have been declared admissible by the Court. ${ }^{47}$ Justice Achour criticised the Court's reference to its previous judgment in the Gombert case which declared the application inadmissible owing to its earlier settlement by the ECOWAS court. In this respect, he pointed out to the differences existing between the ECOWAS court and the HRC, holding that while the former is a sub-regional court which renders legally binding decisions, the latter is a quasi-judicial body whose 'decisions' are not legally binding and thus its views lack res judicata effect. ${ }^{48}$ Without any further reasoning, he objected to the majority's finding and concluded that the case

${ }^{43}$ Hamad Mohamed Lyambaka v. United Republic of Tanzania, supra note 42; Fidèle Mulindahabi v. Republic of Rwanda, ACHPR, Application No 010/2017, judgment of 26 June 2020; Urban Mkandawire v. Republic of Malawi, Application 003/2011, ACHPR, Judgment of 21 June 2013.

${ }^{44}$ Dexter Eddie Johnson v. Republic of Ghana, Application No. 016/2017, Dissenting Opinion of Judge Rafal Ben Achour.

${ }^{45}$ Ibid., para 4.

46 Ibid., para 14.

${ }^{47}$ Ibid., para 2-3.

48 Ibid., para 20-27. 
should have been declared admissible and thus the Court should have proceeded to consider its merits.

Another dissenting opinion was filed by Justice Tchikaya who objected to the decision of the majority regarding the inadmissibility of the case. He labelled the majority finding in the Dexter case a set-back to the development of law. ${ }^{49}$ He noted that this decision denied the African Court the opportunity to promote human rights protection by obliging the respondent state to comply with the previous finding of the HRC. ${ }^{50}$ He further criticised the Court's reliance on its previous approach taken in the Gombert case, arguing that while the Gombert case arose from the sale of a commercial property, the Dexter case concerned the applicant's right to life, which shows the urgency of the situation. ${ }^{51}$ Furthermore, he noted that the African Court should have made an exception to the principle of ne bis in idem and thus declared the case admissible. ${ }^{52}$ To support this rationale, he argued that the current application was different from the one submitted before the HRC especially in that Ghana had refused to give any effect to the finding of the HRC. He further submitted that the importance of the right to life should have convinced the Court that they should make an exception to the rule of ne bis in idem. Lastly, he mentioned Ghana's continued non-compliance with the finding of the HRC as grounds on which the Court should have declared the case admissible. ${ }^{53}$

\section{The Res Judicata Effects of the Findings OF THE ECOWAS COURT OF JUSTICE AND THE HRC}

In international law, the binding force of decisions rendered by competent judicial bodies and tribunals is not contested. ${ }^{54}$ Indeed, the res judicata effects of such decisions are also considered to be uncontroversial.

\footnotetext{
${ }^{49}$ Dexter Eddie Johnson v. Ghana, ACHPR, Application No. 016/2017, Dissenting Opinion of Judge Blaise Tchikaya, para II.

50 Ibid.

51 Ibid., para 21-23.

52 Ibid., para 6.

53 Ibid., para 7-16.

54 Nkhata, supra note 7, p. 487
} 
The controversy arises when discussing whether the decisions of nonjudicial or quasi-judicial bodies have the force of res judicata.

In the Gombert case, the African Court was correct in reaching a conclusion where it recognised the res judicata effect of the ECOWAS court. This is because the ECOWAS court is a sub-regional judicial tribunal established to adjudicate among other things cases related to human rights disputes - a mandate which was extended by the 2005 ECOWAS court Protocol. ${ }^{55}$ Under the 1991 Protocol, the judgments of the ECOWAS court are final and binding upon member states. ${ }^{56}$ The reference framework of the ECOWAS court is the African Charter, as well as other universal instruments for the protection of human rights adopted by the United Nations. ${ }^{57}$ Individuals do not need to pursue domestic remedies for bringing a case before the ECOWAS court. ${ }^{58}$ Nevertheless, for the cases of alleged human rights violation, the applications should not be anonymous and cannot be filed while the same issue is pending before another international court. From the foregoing, it is clear that the ECOWS court is a judicial body which belongs to the category of those bodies envisioned under Article 56 (7) of the African Charter.

The only controversial point of the Gombert cases relates to the position of the Court which recognised the identity of the applicant as the same as that of his company. In this respect, piercing the corporate veil is the reason behind the Court's position. It is because of this that the rights and duties attributed to the AGRILAND company were treated as the rights or liabilities of Mr. Gombert, which in turn meant that the two have the same identity. This position has been supported by other regional human rights courts. ${ }^{59}$

55 Supplementary Protocol A/SP.1/01/05 Amending the Protocol (A/Pl/7/91) Relating to the Community Court of Justice, signed and entered into force in January 2005, art. 3 (4).

56 Revised Treaty of the Economic Community of West African States (ECOWAS), 24 July 1993, art. 15 (4), available at: https://www.refworld.org/docid/492182d92.html (last accessed 6.09.2021).

57 Economic Community of West African States, available at https://www.ecowas. int/institutions/community-court-of-justice/ (last accessed 20.07.2021).

${ }^{58}$ Hadijatou Mani Koraou v. Republic of Niger, ECOWAS, Judgment No. ECW/CCJ/ JUD/06/08, 27 October 2008, para 49.

${ }^{59}$ For example, in the case of Canfos $v$. Argentina, the lnter-American Court of Human Rights held that 'Argentina asserts that legal entities are not included in the American 
In the Dexter case, however, one of the key findings of the African Court was its position which denied the relevance of the non-binding nature or non-implementation of the HRC's views for the purpose of res judicata determination. The first point that should be made here is that non-compliance with a given judgment of a body should not be considered as grounds to deny its res judicata effect. This is because in the international arena, the enforcement of a judgment is a separate issue from its binding character. ${ }^{60}$ International courts and tribunals have very limited tools at their disposal to enforce their decisions, and as such, the execution of their judgments largely depends on the voluntary action and wills of states. ${ }^{61}$ In the light of this, the African Court was correct in reaching the conclusion by which it dismissed the relevance of Ghana's continued non-compliance as grounds for excluding the res judicata effect of the HRC's views.

Moreover, the dissenting opinion of Justice Tchikaya, claiming that the African Court should have made a distinction between the Gombert case and the Dexter application, appears to be misleading. In this context it should be mentioned that while it is true that the essence of the Dexter case touches upon the right to life as opposed to a commercial dispute in the Gombert case, Mr. Gombert did not raise commercial claims before the African Court. In both of these cases, the applicants claimed violation of their human rights under the African Charter. In fact, if Mr. Gombert was bringing a commercial dispute before the African Court, then the Court could not establish its jurisdiction to hear the case under Article 3, and 7 of its founding Protocol. ${ }^{62}$ The African Court was, therefore, correct in not making a distinction between the Gombert case and the Dexter application based on the origins of their disputes.

Convention and, therefore, its provisions are not applicable to them, since they do not have human rights. However, the Court observes that, in general, the rights and obligations attributed to companies become rights and obligations for the individuals who comprise them or who act in their name or representation'.

${ }^{60}$ A. Pellet, "Judicial Settlement of International Disputes", in R. Wolfrum (ed.), Mixed Claims Commissions - Res judicata, Max Planck Encyclopedia of Public International Law, 2013, para 46.

${ }^{61}$ Ibid.; Nkhata, supra note 7, p. 488.

${ }^{62}$ The Protocol on the Establishment of an African Court on Human and Peoples' Rights (adopted 9 June 1981, entered into force 25 January 2004), art. 3, 7. 
However, the authors of this paper do not agree with the position taken by the African Court which dismissed the relevance of the non-binding nature of the HRC's views for the purpose of res judicata determination. In fact, the African Court did not elaborate on how it reached this conclusion. It merely stated that it has "consistently refused to deal with any matter that is pending before the Commission or one that has been settled by the Commission, this notwithstanding the fact that the findings of the Commission are termed 'recommendations', which are not binding." ${ }^{\prime 3}$ In this respect, the Court's reasoning seems to be incoherent and misleading. Looking to its case-law, there is no example in which the African Court was seized with an application that was settled by the Commission. The Court's reference to the case of Urban Mkandawire v. Republic of Malawi rather relates to the question of lis pendens, which is quite a separate issue from the res judicata question. ${ }^{64}$

In the Dexter case, the African Court should first have determined if the issue at hand had been decided by the HRC with the force of res judicata. It was necessary for the Court to elaborate on the implication stemming from the HRC's views, something which could also be of great importance for its jurisprudential development. This assumption has been suggested by the International Court of Justice which in the Genocide case stated that if "a matter has not in fact been determined, expressly or by necessary implication then no force of res judicata [is] attache[d] to it." ${ }^{\prime \prime 5}$ It also stated that for the application of res judicata, "it must deter-

${ }^{63}$ Dexter case, supra note 33, para 54.

${ }^{64}$ Unlike the doctrine of res judicata, the rule of lis pendens governs relations between parallel proceedings. It entails that while an application is under consideration by a judicial body, it is prohibited to start another set of proceedings concerning the same issue before another arbitral body. In the Urban case, the respondent state questioned the admissibility of the case by claiming that the matter was pending before the Commission. The applicant, however, did formally withdraw his communication from the Commission before referring the case to the African Court. The African Court finally declared the case inadmissible owing to the applicant's failure to submit the case within a reasonable time after the exhaustion of local remedies. The African Court, therefore, provided a wrong and misleading reasoning in supporting its argument.

65 Application of the Convention on the Prevention and Punishment of the Crime of Genocide (Bosnia and Herzegovina v. Serbia and Montenegro), Judgment, I.C.J. Report. 2007, para 126. 
mine whether and to what extent the first claim has already been definitively settled." ${ }^{\prime \prime 6}$

Moreover, with regard to the differences in the binding nature of the findings of various human rights bodies, Shany stated that "it should be recognized that various quasi-judicial procedures cannot create an automatic res judicata effect...because they do not produce binding decisions". ${ }^{67}$ This suggests that the implication stemming from the decisions of quasi-judicial bodies should be considered as a determining factor when evaluating their res judicata effect.

Accordingly, to elaborate on the res judicata effect of the HRC's views, it is fruitful to look at its Optional Protocol where the procedure for individual communications is laid out. In accordance with Article 5, the HRC is no court, and it is not empowered to render 'judgments.' Article 5(4) of the Optional Protocol labels the findings of the Committee 'views'. ${ }^{68}$ The views of the HRC do not have the formal quality of judgments and thus are not binding. Domestic courts have frequently and consistently rejected the biding nature of the HRC's views and refused to give effect to its findings. ${ }^{69}$

One may argue for the res judicata effect of the HRC's views by pointing out to General Comment 33 (GC 33) of the $\mathrm{HRC}^{70}$ which stipulates that "while the function of the Human Rights Committee in consider-

${ }^{66}$ Question of the Delimitation of the Continental Shelf between Nicaragua and Colombia beyond 200 nautical miles from the Nicaraguan Coast (Nicaragua v. Colombia), Preliminary Objections, Judgment, I.C.J. Report 2016, para 59.

${ }^{67}$ Shany, supra note 5, p. 173.

68 Optional Protocol to the International Covenant on Civil and Political Rights, 19 December 1966, United Nations, Treaty Series, vol. 999, art. 5 (4).

${ }^{69}$ Austrian Supreme Court, Perterer v. Land Salzburg and Austria, Appeal judgment, 1Ob8/08w, ILDC 1592 (AT 2008), 6 May 2008, para 7-9; Supreme Court of Sri Lanka, Singarasa v. Attorney General, Application for judicial review, SC Spl (LA) No 182/99, ILDC 518 (LK 2006), 15 September 2006, para 21; Spanish Constitutional Court, José Luis PMv. Criminal Chamber of the Supreme Court, Constitutional appeal (recurso de amparo), Judgment of the Constitutional Court, ILDC 1794 (ES 2002), 3 April 2002, para. 17; Supreme Court of Ireland, Kavanagh v. Governor of Mountjoy Prison, Appeal Decision, (2002) 3 IR 97, (2002) 2 ILRM 81; (2002) IESC 13; ILDC 488 (IE 2002), para 36; French Conseil d'Etat, Hauchemaille v. France, Judicial review, No 238849, ILDC 767 (FR 2001) 11 October 2001, para 22; Australia, Federal Court, Minister for Foreign Affairs and Trade v. Magno, 26 November 1992, (1992) 37 FCR 298, 112 ALR 528, para 573.

${ }^{70}$ Nkhata, supra note 7, p. 488-489. 
ing individual communications is not, as such, that of a judicial body, the views issued by the Committee under the Optional Protocol exhibit some important characteristics of a judicial decision", ${ }^{71}$ and it continues to state in paragraph 13 that the "views of the Committee under the Optional Protocol represent an authoritative determination by the organ established under the Covenant itself charged with the interpretation of that instrument". ${ }^{2}$

However, as is clear from GC 33, the HRC is not a judicial body in the sense that it can render decisions that can create an absolute legal obligation on member states to implement them within their respective jurisdictions. Importantly, it is of relevance to mention that the HRC itself noted that state parties are allowed to dismiss its view "after careful consideration, as not reflecting the true legal position with regard to the case concerned". The legal consequence is that member states are only under the obligation to take the HRC's views into consideration in good faith. It can therefore be argued that the views of the HRC under the Optional Protocol do not carry obligatory effect and, as such, they lack the force of res judicata within the meaning of Article 56 (7) of the African Charter.

Looking at other regional human rights systems, one can also argue for the res judicata effect of decisions rendered by quasi-judicial bodies. This is evident in the case of the European system where the Strasbourg court may recognize the res judicata effect of decisions rendered by quasi-judicial bodies. ${ }^{73}$ In this respect, it will be of great importance to consider the socio-political context in which different courts operate. Unlike the ECtHR court where most of the states under its jurisdiction are democratic, the African Court operates in a continent where there is a variety of governmental systems, ranging from democratic states to authoritarian ones. ${ }^{74}$ There are many states engaged in mas-

${ }^{71}$ UN Human Rights Committee (HRC), General comment no. 33, Obligations of States parties under the Optional Protocol to the International Covenant on Civil and Political Rights, 25 June 2009, CCPR/C/GC/33, para. 11, available at: https://www.refworld.org/ docid/4ed34e0f2.html (last accessed 9.08.2021).

72 Ibid., para 13.

${ }^{73}$ Practical Guide on Admissibility Criteria, Council of Europe, European Court of Human Rights, 2021, paras 189-190.

${ }^{74}$ A Leaderless Struggle for Democracy, Freedom in the World 2020, available at: https://freedomhouse.org/report/freedom-world/2020/leaderless-struggle-democracy (last accessed 25.06.2021). 
sive human rights violations related to ongoing civil wars, political instability, humanitarian disasters, and so forth. ${ }^{75}$ Democratic backsliding has become a common phenomenon in many African states. ${ }^{76}$ All of these factors can explain that there will be fewer chances to implement a non-binding order in Africa. This should also be understood in parallel with the reality of international adjudication where parties to a dispute are understood to have less of a tendency to give effect to a non-binding view. ${ }^{77}$

\section{CONCLUSION}

The rule of res judicata is not unique to the African Court. Indeed, the constitutive treaties of many international bodies include provisions regulating the finality of their findings. The rationale behind this makes sense considering the existence of the multiple loci for the dispute resolution. In the absence of such regulation, chaos would, without doubt, reign in the international arena. ${ }^{78}$

This article has shown that the African Court has missed a great opportunity to expand and develop its jurisprudence in relation to the doctrine of res judicata. While the article supported the position of the Court in the Gombert case, it questioned its approach to the Dexter application. It was a mistake for the Court to deal with the Dexter case in the same way as it did in the Gombert application, especially as the latter was resolved by the ECOWAS court - a judicial body whose findings are legally binding and thus amount to the final settlement of disputes between parties. Importantly, the article has argued that the views of the HRC do not have

75 African Union, 47th Activity Report of the African Commission on Human and Peoples' Rights (Submitted to the Policy Organs in accordance with Article 54 of the African Charter on Human and Peoples' Rights).

76 A. Durotoye, "Resurgent Backsliding and Democracy in Africa", International Journal of African and Asian Studies, 2016, Volume 18, Issue 39; S. Hess, R. Aidoo, "Democratic backsliding in sub-Saharan Africa and the role of China's development assistance", Commonwealth $\mathcal{E}$ Comparative Politics, 2019, Volume 57, p. 421.

77 Nkhata, supra note 7, p. 482.

78 Ibid., p. 496. 
the effect of res judicata, considering that the HRC is a non-judicial body which can only render views without a binding force.

The basic conclusion of this article is that the African Court should have, at least, invested more time in its reasoning when elaborating on the non-binding nature of the HRC's views. The article therefore not only challenged the Court's decision in the Dexter case, it also showed its failure in providing a rigorous reasoning for the conclusion it reached in this application. 
